\title{
Ro60 and La ribonucleoproteins become self-aggregated by cell stress
}

\section{Lo stress cellulare induce l'autoaggregazione delle ribonucleoproteine Ro60 e La}

\author{
S.H. Sánchez-Rodríguez, D. Herrera-van Oostdam, E. Avalos-Díaz, R. Herrera-Esparza \\ Department of Immunology, Centro de Biología Experimental, Universidad Autónoma de Zacatecas, Guadalupe, Zacatecas, México
}

\begin{abstract}
RIASSUNTO
Gli antigeni Ro e La sono d'interesse clinico nel lupus subacuto cutaneo in quanto le lesione cutanee che appaiono dopo esposizione solare inducono la traslocazione delle ribonucleoproteine intracellulari Ro e La e innescano la produzione di autoanticorpi. L'obiettivo del nostro studio è determianare se lo stess cellulare è in grado di modificare le caratteristiche molecolari e la distribuzione delle ribonucleoproteine Ro e La. A tale scopo cellule HEp-2 sono state sottoposte a stress cellulare utilizzando calore e radazioni UV, e l'espressione di Ro e La è stata valutata mediante immunofluorescenza, western blot e inmunoprecipitacione utilizzando anticorpi monoclonali anti-Ro/La o anti-HSP70 legati a sepharosa-4B. I risultati confermano che in condizioni di stress cellulare Ro e La, presenti nel nucleo, si ridistribuiscono nel citoplasma e nucleoplasma. Inoltre, lo stress induce l'autoaggregazione delle ribonucleoproteine, come dimostrato dal western blot. Le proteine interagiscono con il citoscheletro via HSP7O.

In conclusione, in condizioni di stress cellulare le proteine Ro e La si ridistribuiscono all'interno del compartimento nucleo-citoplasmatico. Tale ridistribuzione è accompagnata da autoaggregazione e associazione con HSP70. Lo stress cellulare rappresenta quindi un fattore importante per la ridistribuzione antigenica.
\end{abstract}

Reumatismo, 2007; 59(4):292-298

\section{INTRODUCTION}

$\mathrm{R}$ $\mathrm{o}$ is a cellular particle composed by three ribonucleoproteins of 60,54 and $52 \mathrm{kDa}(1-3)$. Ro60 forms a complex with one of the 1-5 hYRNAs (4). Antigenic properties of Ro were described by Clark in 1969 using autoimmune sera (5), and it is broadly accepted that Ro is recognized by autoantibodies from patients with systemic lupus erythematosus (SLE), subacute cutaneous lupus erythematosus (SCLE), Sjögren's syndrome (SS) and neonatal lupus (6). Complexes of Ro are involved in the transcription quality control of 5S rRNA, Ro60 bind the 5S rRNA inefficient transcribed to be eliminated $(7,8)$. Ro is expressed broadly in nucleus and cytoplasm of eukaryotic cells (9-11). Anti-Ro

Indirizzo per la corrispondenza:

Rafael Herrera-Esparza

MD Chepinque 306

Col. Lomas de la Soledad

Zacatecas 98040, México

E-mail: herrerar@uaz.edu.mx antibody is of clinical interest because is associated to SCLE. Apparently Ro is released by keratinocytes exposed to UV irradiation, which presumably trigger the cutaneous lesions by local anti-Ro/La antibodies deposition, that in turn activate a cytotoxic mechanism dependent of antibodies (6). Recently has been disclosed that Ro52 is a RINGdependent E3 ligase involved in ubiquitination, and its increased expression in patients may be directly involved in reducing cellular proliferation and increasing apoptotic cell death observed in Sjögren's syndrome and SLE, this is important because a enhanced expression of Ro52 in tissues, result in an increase of apoptoic remains in tissues (12).

$\mathrm{La}$ antigen is a $48 \mathrm{kDa}$ ribonucleoprotein that plays a role in transcription as termination factor (13). The activity of La antigen depends on phosphorylation and de-phosphorylation cycles (14); this process also affects its antigenicity $(15,16)$. La autoantibody is of clinical interest because of its association with the Sjögren syndrome and SCLE (6). Sera with anti-La specificity generally possess 
anti-Ro antibodies; this suggests that Ro and La antigens are clustered $(17,18)$.

In SCLE, solar irradiation constitutes the major stressor of the skin, because it contains both UV waves and caloric stress; in SCLE the relapses of skin lesions are frequently associated with sun exposure, which probably enhances the antigen expression that is followed by auto-antibody production. The exposure to those stressors triggers a physiological response and the transcription of heat shock proteins (HSP); being the most important HSP70, which play a role in degradation, refurbishing and reactivation of damaged proteins.

Present studies address the issue whether the stress affects the expression, distribution and possible conformational changes of Ro60 and La antigens, and its possible association with the cytoskeleton. Since HSP70 is constitutive and ubiquitously protein distributed in cell compartments (19), HSP70 was included as monitor of cell stress, during this study its possible relationship with Ro, La and cytoskeleton proteins was assessed.

\section{MATERIAL AND METHODS}

\section{Cell culture}

HEp-2 cells (ATTC) were grown in DMEM media (Sigma St. Louis, Mo.) with penicillin $(100 \mathrm{U} / \mathrm{ml})$, streptomycin $(100 \mathrm{mg} / \mathrm{ml})$, insulin $(0.08 \mathrm{U} / \mathrm{ml})$, and $10 \%$ fetal bovine serum (Gibco BRL, Grand Island, N.Y) at $37.5^{\circ} \mathrm{C}$, in a $5 \% \mathrm{CO}_{2}$ atmosphere of. Cells growing in logarithmic phase were harvested by means of trypsin EDTA and plated at confluence for experiments with stressors $\left(5 \times 10^{6} / \mathrm{ml}\right)$.

\section{Cell stressors}

Cultures were irradiated at $366 \mathrm{~nm}$ using a UV-A lamp (Black-Ray lamp UVL-56), archiving a dose of $5-30 \mathrm{~mJ} / \mathrm{cm}^{2}(20)$. Control cells were cultured and manipulated without irradiation. Caloric stress was done by raising the temperature of cell cultures from $37^{\circ} \mathrm{C}$ to $40^{\circ} \mathrm{C}, 42^{\circ} \mathrm{C}$ and $44^{\circ} \mathrm{C}$ respectively, for a duration of 3 hours.

\section{Protein extraction}

Stressed and non-stressed cells were harvested as described and spun at $1200 \mathrm{rpm}$ for 10 minutes. The cellular pellets were resuspended in denaturing lysis buffer (1\% SDS, 0.25 M EDTA, $1 \mathrm{mM}$ Tris, $\mathrm{pH} 7.5$, and $1 \mathrm{mM}$ PMSF; adjusted to $1 \mathrm{ml}$ $\mathrm{H} 2 \mathrm{O})$. Soluble antigens were extracted by sonication: 5 pulses of 30 seconds at $50 \%$. The lysates were centrifuged at $12000 \mathrm{rpm} / 10$ minutes and the supernatants were immediately used for analysis. The protein concentration was measured at 280 $\mathrm{nm}$. The insoluble fractions were extracted by 30 minutes incubation with a urea buffer $[1.5 \mathrm{M} \mathrm{KCl}$, $0.5 \%$ Triton X-100, 5 mM EDTA, 1 mM PMSF, in $10 \mathrm{mM}$ Tris- $\mathrm{HCl}$, and $\mathrm{pH} 7.6$ with $8 \mathrm{M}$ urea].

\section{ELISA test}

Stressed and non-stressed HEp-2 cell extracts were used for coating the polystyrene plates, after washings with PBS; the uncoated sites were blocked 1 hour with 3\% BFS-PBS. Following washings, the coated plates were incubated overnight with antiRo; anti-La or anti-HSP70 antibodies diluted $1: 3000$ in $3 \%$ BFS-PBS. Plates were further washed and bound antibodies were tagged with goat anti-mouse IgG HRP-labeled. Color was induced by 2, 2 diaminobenzydine and $0.06 \% \mathrm{H}_{2} \mathrm{O}_{2}$. The reaction was stopped with $2 \mathrm{~N}$ sulphuric acid; optical density was determined at $490 \mathrm{~nm}$ in a BioRad ELISA reader. All assays were made in triplicate (21). Data was processed by student t-Test (Prisma program); $\mathrm{p}<0.005$ was considered statistically significant.

\section{SDS-PAGE and Western blot}

Cellular extracts were submitted to $15 \%$ sodium dodecyl sulphate polyacrylamide gel electrophoresis (SDS-PAGE) under reducing conditions, as described by Laemmli and Favre (22); non-reducing conditions were also applied in the absence of bismercaptoethanol or DTT in the sample buffer. The unstained gels were blotted onto nitro-cellulose membranes using the procedure described by Towbin et al. (23). Non-specific active sites were blocked with $1 \%$ non-fat milk. Immunorreactive bands were identified with a 1:1000 dilution of monoclonal anti HSP70, anti-Ro or anti-La antibodies. 1:1000 in phosphate saline buffer (PBS). Bound antibodies were detected with rabbit antimouse IgG-HRPC (Sigma. St Louis, MO). Immunoreactive bands were visualized with an ECL chemiluminescent kit (Amersham Pharmacia Biotech. Piscataway, NJ). The bands were recorded using an image analysis system. The molecular weights at the immunoreactive bands could be determined by comparison with standards of known molecular mass (BioRad, Richmond. CA).

\section{Crossed-Immunoprecipitation}

Cell extracts were immunoprecipitated with antiRo, anti-La and anti-HSP70, anti-Tubulin, anti 
Actin or anti-Cytokeratin antibodies linked to $\mathrm{CN}$ $\mathrm{Br}$ activated 4B Shepharose (Sigma, St Louis Mo) and dissolved in $50 \mathrm{mM}$ tris, $\mathrm{pH}$ 7.0. Cell extracts and immunoadsorbents were mixed, incubated and rocked at room temperature overnight. After extensive washings; immunoprecipitates were eluted with $0.1 \mathrm{M}$ glycine at $\mathrm{pH} 3.0$, followed by neutralization with $1 \mathrm{M}$ Tris-base, $\mathrm{pH}$ 9.0; and characterized by SDS-PAGE, were blotted and tagged with anti-Ro, anti-La or anti-HSP70, or with anti actin, tubulin and cytokeratin, or vice versa, immunoreactive bands disclosed by autoradiography as previously described.

\section{Double fluorescent labeling}

Ro, La and HSP70 co-localization with cytoskeleton components was defined by a double labeling. The first incubation with anti-Ro, anti-La or antiHSP70 was followed by $1 \mathrm{hr}$ incubation with FITC labeled secondary antibody (sheep anti-mouse; Cappel, West Chester, PA). After extensive washings, a third incubation with anti-actin, b-tubulin and cytokeratin was carried out, followed by a red tagging with RITC-goat anti-mouse (Sigma). Finally, the slides were washed, mounted and examined under a confocal scanning microscope LSM (Axiovert 200M, Carl Zeiss, Göttingen Germany). Fluorescein and rodamine filter combinations with excitations of 450-490 $\mathrm{nm}$ and emissions of 515$565 \mathrm{~nm}$ were used respectively, objectives were LCI "Plan-Neofluar" and the image processing was done by a Zeiss LSM Image examiner.

\section{Antibodies}

The following monoclonal antibodies were used: anti-Ro60 monoclonal antibody which recognized a single band at $60 \mathrm{kDa}$ level and anti-La monoclonal antibody recognizing a single $48 \mathrm{kDa}$ band (24); these monoclonals were generously donated to our laboratory by R.T. Smeenk from the CLB (Amsterdam), also were used anti-HSP70 mono- clonal antibody (H-5147) anti-actin (A-4700), anti-b-tubulin (T-5168) and anti-cytokeratins H-4840) which were obtained commercially (Sigma, St Louis MO).

\section{RESULTS}

\section{Stress enhances Ro and La expression}

HSP70 was used as cell stress monitor; and its expression was significantly superior in extracts of stressed cells as demonstrated the ELISA assays. According to our previous findings Ro and La expression were increased in extracts from cells UV irradiated or submitted to caloric stress (Tab. I).

\section{Stress induces Ro and La self-aggregation}

We were able to demonstrate by Western blot an increase of the Ro and La intensity bands of stressed cell extracts. Interestingly, the extracts of the soluble fraction exhibited two additional bands of Ro. Meanwhile La display additional bands mainly in the insoluble fraction of heated cells. To elucidate if bands corresponded to self-aggregate or belonged to degradation protein fragments, the cell extracts containing the possible aggregates of Ro and La, were additionally electrophoresed under reducing conditions. Interestingly, the bis-mercaptoethanol and/or DTT induced Ro and La disaggregating and produced unique bands; this result confirms that the dimmers and trimmers of Ro and La induced by stress correspond to self aggregates (Fig. 1).

\section{Ro and La co-localize with the cytoskeleton}

The presence of Ro and La proteins in the insoluble fraction of stressed cells, suggested some kind of association between these ribonucleoproteins and the cytoskeleton, to confirm such association a double fluorescence assay tagging the Ro and $\mathrm{La}$ proteins in green, and the cytoskeleton proteins in

Table I - ELISA values of Ro, La and HSP70 proteins.

\begin{tabular}{|lccccccc|}
\hline & Control & UV $1 h$ & UV $2 h$ & UV $3 h$ & $40{ }^{\circ} \mathrm{C}$ & $42{ }^{\circ} \mathrm{C}$ & $44^{\circ} \mathrm{C}$ \\
\hline Ro & $134.4 \pm 0.2330$ & $210.3 \pm 0.5925$ & $290.3 \pm 0.4924$ & $381.3 \pm 0.7647$ & $381.3 \pm 0.7647$ & $450.3 \pm 0.5115$ & $471.4 \pm 0.5274$ \\
$\mathrm{p}<$ & vs & 0.0052 & 0.0181 & 0.0008 & 0.0008 & 0.0141 & 0.0081 \\
La & $134.2 \pm 0.1374$ & $349.2 \pm 3.048$ & $392.1 \pm 0.0690$ & $410.8 \pm 0.2948$ & $389.9 \pm 0.3167$ & $430.7 \pm 0.2656$ & $471.7 \pm 0.8337$ \\
$\mathrm{p}<$ & vs & 0.0001 & 0.0262 & 0.0164 & 0.0103 & 0.0314 & 0.0001 \\
HSP70 & $131.7 \pm 0.4156$ & $471.7 \pm 0.8337$ & $490.7 \pm 0.2242$ & $520.6 \pm 0.1899$ & $550.4 \pm 0.1618$ & $680.1 \pm 0.1838$ & $720.1 \pm 0.1709$ \\
p value & vs & 0.0250 & 0.0401 & 0.0144 & 0.0048 & 0.0117 & 0.0071 \\
\hline Significant p value $<0.05$ & & & & & & \\
\hline
\end{tabular}




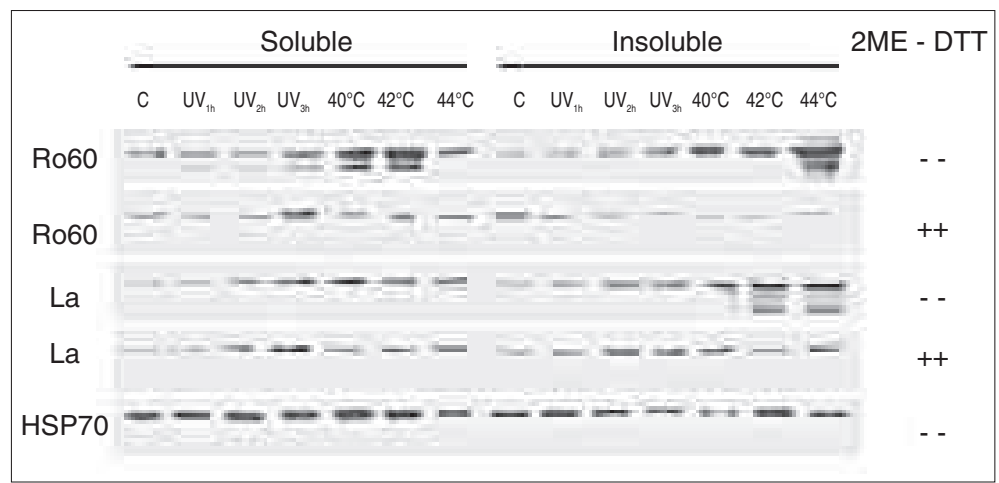

Figure 1 - Expression of Ro, La, HSP70 in control (c) and stressed HEp-2 cells studied by Western blot, that show aggregates of Ro soluble species and La insoluble (pellet) species, in reducing $(2 \mathrm{ME}=$ bis-mercaptoethanol., DTT = Dithiothreitol) and non reducing conditions. HSP70 was included as housekeeping protein in the bottom. red was done. The main result of this assay demonstrated that Ro and La ribonucleoproteins did not co-localize with the cytoskeleton proteins of control cells, however, under stress there was co-localization of Ro, La and HSP70 with tubulin and/or actin (Fig. 2).
The localization of Ro and La proteins in the cytoskeleton depends of HSP70

Taking in to account our previous findings, the interaction between the cytoskeleton and HSP70 and $\mathrm{Ro} / \mathrm{La}$ ribonucleoproteins was further studied by crossed-immunoprecipitation. The results of this

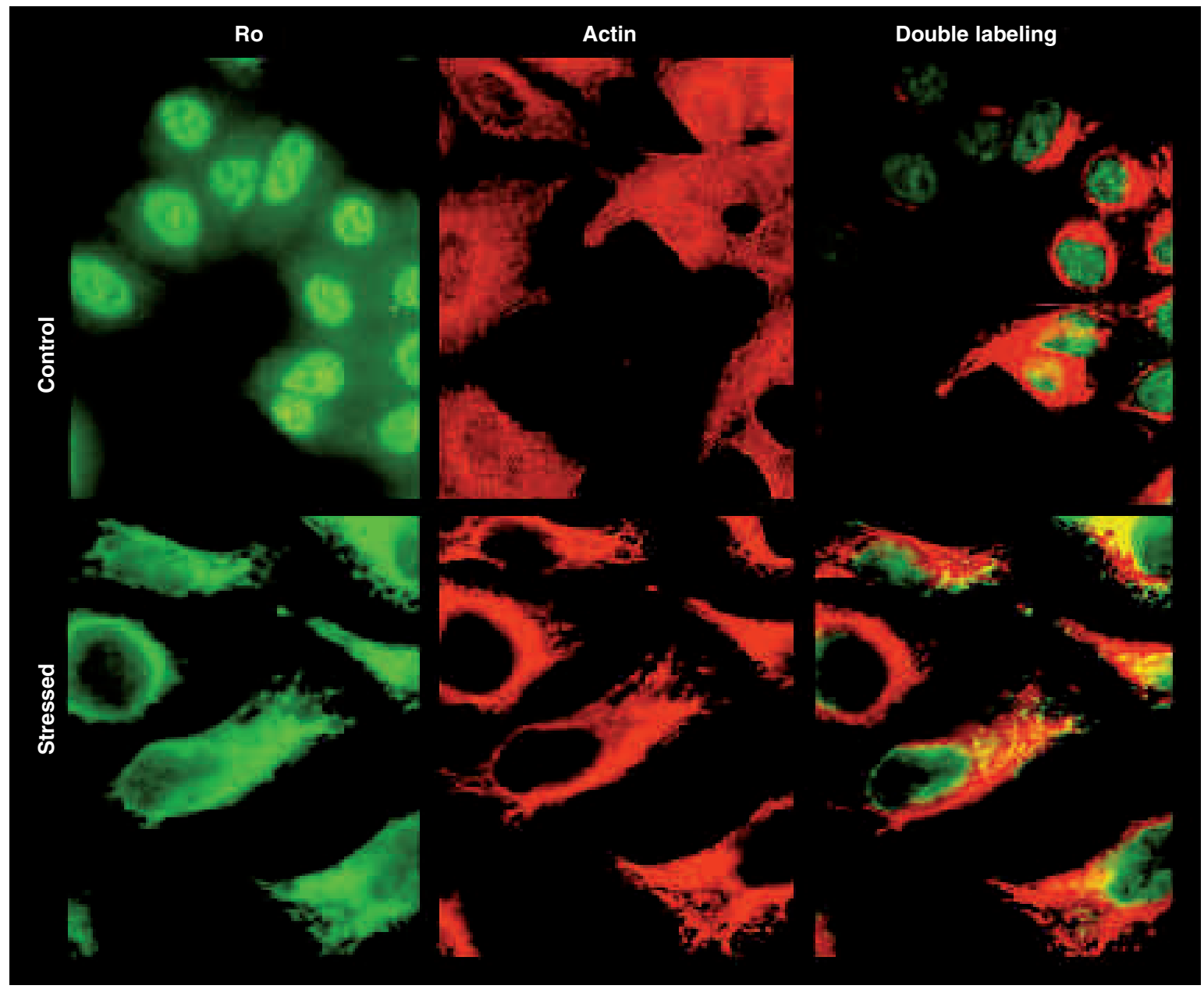

Figure 2 - Double fluorescence assay of Ro and La proteins double tagged in green, and the cytoskeleton proteins in red. A representative colocalization of Ro with actin in stressed HEp-2 cells. 


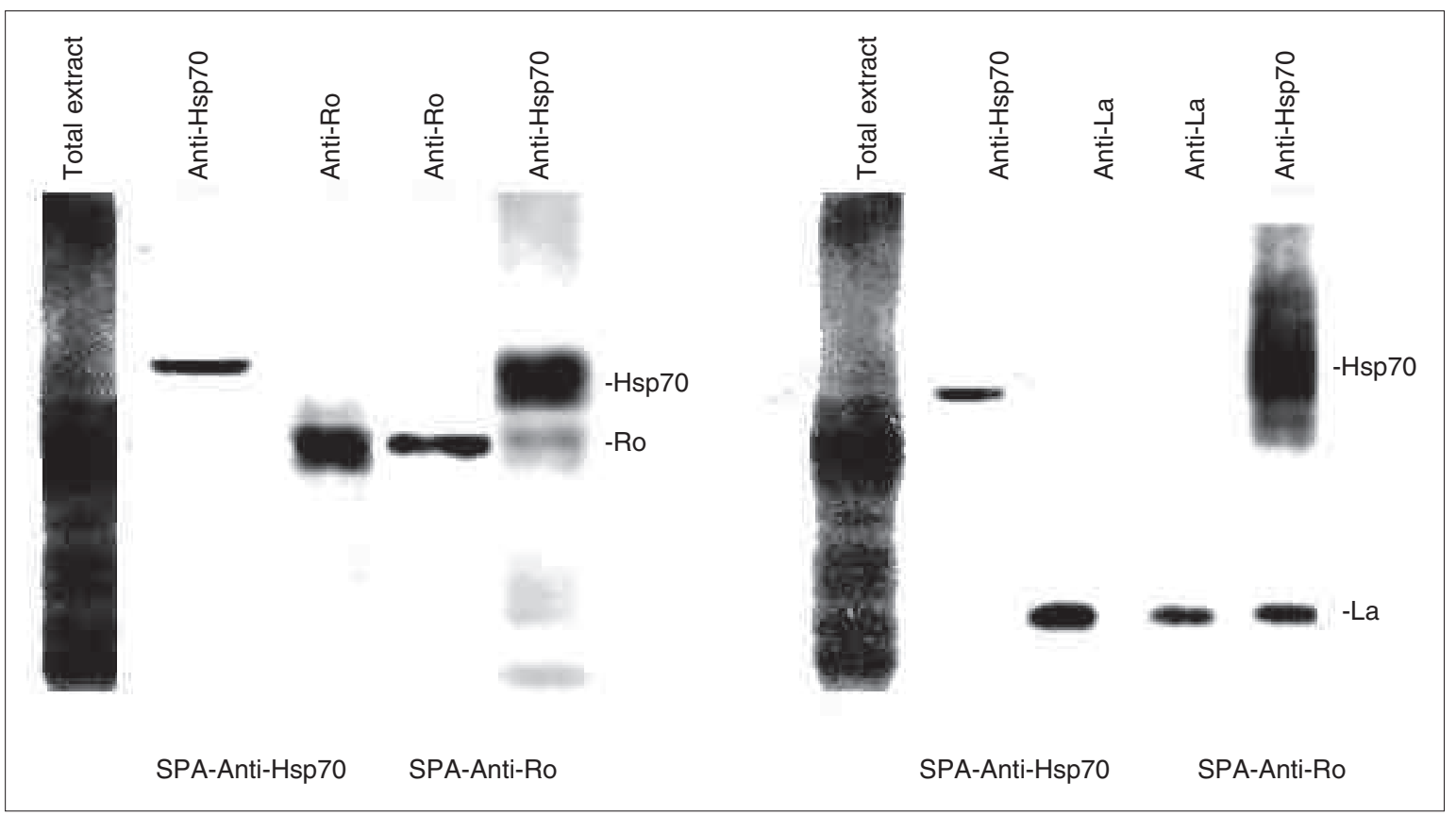

Figure 3 - Co-precipitation assays with anti-HSP70 linked to CNBr-4B Sepharose and co-precipitates were tagged with anti-Ro, anti-La or vice versa.

assay did not show precipitation of Ro and La by cytoskeleton proteins, however the HSP70 was coprecipitated by anti-actin and anti-tubulin antibodies, and in turn HSP70 precipitates simultaneously $\mathrm{Ro} / \mathrm{La}$ and cytoskeleton proteins. This finding suggests that the association of Ro and La ribonucleoproteins with the cytoskeleton proteins are HSP70 dependent (Fig. 3).

\section{DISCUSSION}

Present studies address the molecular modifications of Ro and La ribonucleoproteins induced by stress. Main results of present studies demonstrated that the stress redistributes Ro and La ribonucleoproteins in cell compartments and induce conformational changes by self-aggregation.

Cellular stress is a physiological condition triggered by heat, glucose starvation, radiation and others. By stress the transcription of heat shock proteins (HSP) is activated; and HSP play a role in degradation, refurbishing and reactivation of damaged proteins (25). The stress induces changes of the cytoskeleton which is of particular importance because the actin-based cytoskeleton is a sensitive monitor of extra cellular stimuli $(26,27)$.

Is well established that stress increases the avail- ability of intracellular antigens on cell surface, in consequence the autoantibodies trigger better antigens produced under cellular stress $(28,29)$, present results confirm this notion, and suggest that the Ro and La redistribution is associated to the cytoskeleton modification; another interesting observation suggest that Ro and La suffer conformational changes and aggregates form transitory complexes with the cytoskeleton proteins through HSP70. As support to our Ro ad La proteins tagged another experimental model have been demonstrated that under UV irradiation Ro and La are shuttled to cell membrane associated to calreticulin and HSP proteins, the transport is executed by the cytoskeleton (30-32).

Current work is of clinical importance because mimics stressful conditions like sunlight exposure that produce flare-ups in lupus, and increases the expression of Ro and La antigens on cell surface; this is followed by in situ formation of immune complexes of Ro/La and anti-Ro and/or anti-La antibodies that in turn trigger the skin lesions (29). For this reason it was important to define whether the UV and caloric stress induced conformational changes of Ro60 and La molecules that could affect its antigenicity. Present studies demonstrate that Ro60 and La self-aggregates under stress, this molecular modification was demonstrated previ- 
ously in situ $(1,34,35)$, Ro60 may form aggregates in vitro, and induce complexes with other proteins such as nucleolin, calreticulin, hnRNP K, and hnRNP the latter with chaperone activity $(35,36)$. Present investigation was carried out in vivo, and demonstrates that cell stress induce self-aggregation of Ro and La ribonucleoproteins, also shows association of these ribonucleoproteins with HSP70, this result suggest that HSP70 $\mathrm{r}$ may play a role as a carrier of Ro and La during their transit to cell membrane (37), another subrogate function of HSP70 may be in refurbishing the self-aggregates of Ro and La ribonucleoproteins. The importance of present studies is the experimental verification that stress produces self-aggregation Ro and La proteins and this conformational modification enhances their antigenicity. The antigenic expression in patients with autoimmune diseases, is important because favor the targeting of anti-Ro or anti La antibodies in tissues of Sjögren, SCLE and neonatal lupus (38). In conclusion, the cell stress redistributes Ro and La proteins whiting nucleo-cytoplasmic compartments. This redistribution is accompanied by self aggregation of Ro and La which interact with the cytoskeleton through HSP70. Finally the cell stress is an important factor for antigenic redistribution.

\section{Acknowledgements}

This work was financially supported by PROMEP

\begin{abstract}
SUMMARY
Ro and La antigens are of clinical interest in subacute cutaneous lupus erythematosus because skin lesions appear after UV irradiation, which induces the translocation of intracellular Ro and La ribonucleoproteins and trigger autoantibody production. Present studies address the question whether cellular stressors modify molecular characteristics and distribution of Ro60 and La proteins. To accomplish our goal HEp-2 cells were stressed by heat and UV irradiation and Ro and La expression was studied by indirect immunofluorescence and Western blot and crossed-immunoprecipitation using monoclonal anti-Ro/La or anti-HSP70 linked to CNBr-Sepharose 4B.

Results of present studies confirm that Ro60 and La were located in the nuclei of non stressed cells; however under stress, both ribonucleoproteins were redistributed within cytoplasm and nucleoplasm, interestingly the stress induces self aggregation of both ribonucleoproteins, as demonstrated the Western blot assays. Ro and La proteins interact with the cytoskeleton protein via HSP70.

In conclusion, the cell stress redistributes Ro and La proteins whiting nucleo-cytoplasmic compartments. This redistribution is accompanied by self aggregation of Ro and La which became associated with HSP70. Finally, the cell stress is an important factor for antigenic redistribution.
\end{abstract}

Parole chiave - Antigeni Ro-60, anticorpi anti-Ro, antigeni La, stress cellulare, ribonucleoproteine.

Key words - Ro60 antigen, anti-Ro antibodies, la antigen, anti-La antibodies, cellular stress, ribonucleoproteins.

\section{REFERENCES}

1. Elkon K, Culhane L. Partial immunochemical characterization of Ro and La proteins using antibodies from patients with sicca syndrome and lupus erythematosus. J Immunol 1984; 132: 2350-6.

2. Ben-Chetrit E, Chan EK, Sullivan KF, Tan EM. A 52 $\mathrm{kD}$ protein is a novel component of the SS-A/Ro ribonucleoprotein autoantigen. J Exp Med 1988; 167: 156071.

3. Rader MD, O'Brien C, Liu YS, Harley JB, Reichlin M. Heterogeneity of the Ro/SS-A antigen. Different molecular forms in lymphocytes and red blood cells. J Clin Invest 1989; 83: 1293-8.

4. Wolin S, Steitz J. Genes for two small cytoplasmic RoRNAs are adjacent and appear to be a single-copy in the human genome. Cell 1983; 32: 735-44.

5. Clark G, Reichlin M, Tomasi TB. Characterization of a soluble cytoplasmic antigen reactive with sera from patients with systemic lupus erythematosus. J Immunol 1969; 102: 117-22.

6. Provost TT, Herrera-Esparza R, Diaz LA. Nucleoprotein autoantibodies in lupus erythematosus. J Invest Dermatol 1985; 85: 133s-139s.

7. O'Brien CA, Wolin SL. A possible role for the $60 \mathrm{kD}$ Ro autoantigen in a dischard pathway for defective $5 \mathrm{~S}$ rRNA precursors. Genes \& Dev 1994; 8: 2891-903.

8. Campos-Almaraz M, Fraire-Velazquez S, Moreno J, Herrera-Esparza R. The 5S rRNA is associated with Ro60 ribonucleoprotein and is co-precipitated with hYRNAs by anti-Ro antibodies. Autoimmunity 1999; 31: 95-101.

9. López-Robles E, Herrera-Esparza R, Avalos-Díaz E. Cellular localization of the Ro/SS-A antigen. Clin Rheumatol 1986; 5: 33-8.

10. López-Luna A, Ramírez-Santoyo RM, Barbosa-Cisneros OY, Avalos-Díaz E, Herrera-Esparza R. Phosphorylation profiles of $60 \mathrm{kD}$ Ro antigen in synchronized HEp-2 
cells. Scand J Rheumatol 1994; 24: 293-9.

11. Simons FH, Pruijn GJM, van Venrooij WJ. Analysis of the intracellular localization and assembly of Ro ribonucleoprotein particles by microinjection into Xenopus laevis oocytes. J Cell Biol 1994; 125: 981-988.

12. Espinosa A, Zhou W, Ek M, Hedlund M, Brauner S, Popovic K, Horvath I, Wallerskog T, Oukka M, Nyberg F, Kuchroo VK, Wahren-Herlenius M. The Sjogren's syndrome-associated autoantigen Ro52 is an E3 ligase that regulates proliferation and cell death. J Immunol 2006; 176: 6277-85.

13. Gottlieb E, Steitz JA. Function of the mammalian La protein: evidence for its activity in transcription termination by RNA polymerase III. EMBO J 1989; 8: 85161.

14. Bachmann M, Pfeifer K, Shröder HC, Müller WEG. Characterization of the La as a nucleic acid-dependent ATPase/dATPase with melting properties. Cell 1990; 60: 85-93.

15. Utz P, Hottelet M, Schur P, Anderson P. Proteins phosphorylated during stress-induced apoptosis are common targets for autoantibody production in patients with systemic lupus erythematosus. J Exp Med 1997; 185: 843-54.

16. Utz PJ, Hottelet M, van Venrooij WJ, Anderson P. Association of phosphorylated serine/arginine (SR) splicing factors with the U1-small ribonucleoprotein (snRNP) autoantigen complex accompanies apoptotic cell death. J Exp Med 1998; 187: 547-60.

17. To $\mathrm{CH}$, Petri M. Is antibody clustering predictive of clinical subsets and damage in systemic lupus erythematosus? Arthritis Rheum 2005; 52: 4003-10.

18. Hendrick JP, Hartl FU. Molecular chaperone functions of heat-shock proteins. Annu Rev Biochem 1993; 62: 349-84.

19. Leverkus M, Yaar M, Eller MS, Tang EH, Gilchrest BA. Post-transcriptional regulation of UV induced TNF-alpha expression. J Invest Dermatol 1998; 110: 353-7.

20. Herrera-vanOostdam DA, Esparza-Ibarra E, RamirezSandoval R, Ortiz V, Bollain-y-Goitia JJ, Avalos-Diaz E, Herrera-Esparza R. Apoptosis and necrosis increase antigenicity of proteins recognized by antinuclear antibodies. Reumatismo 2004; 56: 156-61.

21. Laemmli UK, Favre M. Maturation of the head of bacteriophage T4 I DNA packaging events. J Mol Biol 1973: 80: 575-99.

22. Towbin H, Staehlin T, Gordon J. Electrophoretic transfer of proteins from polyacrylamide gels to nitrocelulose sheets: Procedure and some applications. Proc Natl Acad Sci. USA 1979; 76: 4350-4.

23. Veldhoven CH, Pruijn GJ, Meilof JF, Thijssen JP, van der Kemp AW, van Venrooij WJ, Smeenk RT. Characterization of murine monoclonal antibodies against 60-kD Ro/SS-A and La/SS-B autoantigens. Clin Exp Immunol 1995; 101: 45-54.

24. Parsall DA, Lindquist S. The function of heat-shock proteins in stress tolerance: degradation and reactivation of damaged proteins. Ann Rev Genet. 1993; 27 : 437-96.
25. Liu X, Shu S, Hong MS, Levine RL, Korn ED. Phosphorylation of actin Tyr-53 inhibits filament nucleation and elongation and destabilizes filaments. PNAS 2006; 103: 13694-9.

26. Kim JH, Kim HW, Jeon H, Suh PG, Ryu SH. Phospholipase D1 regulates cell migration in a lipaseactivity-independent manner. J Biol Chem 2006; 81: 15747 56.

27. Du L, Fukushima S, Sallmyr A, Manthorpe R, Bredberg A. Exposure of HEp-2 cells to stress conditions influences antinuclear reactivity. Clin Diag Lab Immunol 2000; 9: 287-94.

28. Herrera-Esparza R, Villalobos R, Bollain-y-Goytia JJ, Ramirez-Sandoval R, Sánchez-Rodriguez SH, Pacheco-Tovar G, et al. Apoptosis and redistribution of the Ro autoantigen in Balb/c mouse like in subacute cutaneous lupus erythematosus. Clin Dev Immunol 2006; 13: 163-6.

29. LeFerber WP, Norris DA, Ryan SR, Huff JC, Lee LA, Kubo M, et al. Ultraviolet light induces binding of antibodies to select nuclear antigens on cultured human keratinocytes. J Clin Invest 1984; 74: 1545-51.

30. Bachman M, Chang SH, Slor H, Kukulies J, Muller WEG. Shuttling of the autoantigen La between the nucleus and cell surface after UV irradiation of human keratinocytes. Exp Cell Res 1990; 191: 171-80.

31. Furukawa F, Lyons MB, Coulter SN, Norris DA. Estradiol enhances binding to cultured human keratinocytes of antibodies specific for SS-A/Ro and SS-B/La. J Immunol 1988; 141: 1480-8.

32. McCauliffe DP, Sontheimer RD. Molecular characterization of the Ro/SS-A autoantigens. J Invest Dermatol 1993; 100: 73S-79S.

33. Eggleton P. Stress protein-polypeptide complexes acting as autoimmune triggers. Clin Exp Immunol 2003; 134: 6-8.

34. Staikou EV, Routsias JG, Makri AA, Terzoglou A, Sakarellos-Daitsiotis M, Sakarellos C, et al. Calreticulin binds preferentially with B cell linear epitopes of Ro60 $\mathrm{kD}$ autoantigen, enhancing recognition by anti-Ro60 kD autoantibodies. Clin Exp Immunol 2003; 134: 143-50.

35. Belisova A, Semrad K, Mayer O, Kocian G, Waigmann E, Schroeder R, et al. RNA chaperone activity of protein components of human Ro RNPs. RNA 2005, 11: 1084-94.

36. Fouraux MA, Bouvet P, Verkaart S, van Venrooij WJ, Pruijn GJ. Nucleolin associates with a subset of the human Ro ribonucleoprotein complexes. J Mol Biol. 2002; 320: 475-88.

37. Villalobos-Hurtado R, Sanchez-Rodriguez SH, AvalosDiaz E, Herrera-Esparza R. Possible role of Hsp70 in autoantigen shuttling to the dermo-epidermal junction in systemic lupus erythematosus. Reumatismo 2003; 55: $155-8$.

38. van Woerkom JM, Geertzema JG, Nikkels PG, Kruize AA, Smeenk RJ, Vroom TM. Expression of Ro/SS-A and La/SS-B determined by immunohistochemistry in healthy, inflamed and autoimmune diseased human tissues: a generalized phenomenon. Clin Exp Rheumatol 2004; 22: 285-92. 